Copyright by the American Society of Agricultural and Biological Engineers. Sparks, J. A.; Ogejo, J. A.; Cyriac, J.; Hanigan, M. D.; Knowlton, K. F.; Gay, S. W.; Marr, L. C., "The effects of dietary protein content and manure handling technique on ammonia emissions during short-term storage of dairy cow manure," Transactions of the ASABE. 54(2): 675-683. (doi: 10.13031/2013.36470) @2011

\title{
The Effects of Dietary Protein Content and Manure Handling TeChNique on Ammonia Emissions during Short-Term Storage of Dairy Cow Manure
}

\author{
J. A. Sparks, J. A. Ogejo, J. Cyriac，M. D. Hanigan， K. F. Knowlton，S. W. Gay， L. C. Marr
}

\begin{abstract}
An improved understanding of the potential for dietary protein manipulation to reduce ammonia emissions from dairy farms during various stages of manure handling is needed for both modeling and policy-making efforts. The objective of this study was to assess the effects of dietary protein manipulation on ammonia emissions from relatively freshly voided dairy cow manure in three types of removal systems: scraped manure removal systems, flushed manure removal systems, and flushed manure removal systems with a solids separator. Emissions were measured using a dynamic flux chamber for $12 \mathrm{~h}$ or more. Ammonia fluxes and emission factors per mass of manure were not affected by dietary protein content because fluxes depended mainly on total ammoniacal nitrogen (TAN) concentration, which did not vary with diet. However, emissions on a per-cow basis were $12 \%$ lower with the diet containing $15.0 \%$ crude protein as compared to the one with $17.8 \%$ (a change in crude protein of 16\%) due to reduced urine output. The largest absolute impact of dietary protein manipulation would be with separated liquids because their emission factor was approximately four times higher than for the other types of manure. While dietary protein manipulation can reduce ammonia emissions from manure during long-term storage, its effectiveness in the hours immediately after manure is excreted is limited because emissions are more sensitive to other factors, including temperature and extent of mixing of the manure, that vary widely under real operating conditions on a farm.
\end{abstract}

Keywords. Air quality, Ammonia emission, Dairy cows, Dietary manipulation, Manure, Manure management.

A mmonia is a key ingredient in the formation of fine particulate matter $\left(\mathrm{PM}_{2.5}\right)$, whose deleterious effects on health, visibility, and global climate are well documented. The majority of ammonia emissions originate from agriculture, and a recent review of their impacts on air quality deems the policy-making and regulation challenging and controlling of emissions notoriously difficult (Aneja et al., 2009). New regulations are likely to be introduced, and improved understanding of the effectiveness of various management practices on ammonia emissions from animal feeding operations (AFOs) is needed.

Control strategies for reducing ammonia emissions from AFOs include optimization of diet, housing practices, manure storage, and land application techniques (McCubbin et al., 2002; Ndegwa et al., 2008; Novak and Fiorelli, 2010).

Submitted for review in November 2010 as manuscript number SE 8904; approved for publication by the Structures \& Environment Division of ASABE in February 2011.

The authors are Jeffrey A. Sparks, Graduate Student, Department of Civil and Environmental Engineering, Jactone Arogo Ogejo, ASABE Member Engineer, Assistant Professor, Department of Biosystems Engineering, Joby Cyriac, Graduate Student, and Mark D. Hanigan, Associate Professor, Department of Dairy Science, Katharine F. Knowlton, Professor, Department of Dairy Science, Susan W. Gay, former Assistant Professor, Department of Biosystems Engineering, and Linsey C. Marr, Associate Professor, Department of Civil and Environmental Engineering, Virginia Tech; Blacksburg, Virginia. Corresponding author: Linsey C. Marr, Department of Civil and Environmental Engineering, Virginia Tech; 411 Durham Hall, Blacksburg, VA 24060; phone: 540-231-6071; fax: 540-231-7916; e-mail: 1marr@vt.edu.
Among these, dietary optimization is estimated to have the largest potential to reduce emissions from livestock farms (McCubbin et al., 2002). This approach reduces the amount of nitrogen excreted (Smits et al., 1995; Tomlinson et al., 1996), and reductions in emissions of ammonia follow, as demonstrated for cattle manure at a variety of scales, including bottles (James et al., 1999; Paul et al., 1998; van der Stelt et al., 2008), flux chambers (Burgos et al., 2010; Frank et al., 2002; Frank and Swensson, 2002; Krober et al., 2000; Kulling et al., 2003; Todd et al., 2006), and barns (Powell et al., 2008; Smits et al., 1995). Together, these studies suggest that a reduction in dietary protein will result in a reduction in ammonia emissions from dairy farms.

Still, an improved understanding of how ammonia emissions are affected by the interaction of diet and manure handling system is needed for the development of models to predict ammonia fluxes from AFOs. Improved understanding of this interaction will also aid in the development of science-based strategies for reducing ammonia emissions from farms. It is possible that dietary protein manipulation for the reduction of ammonia emissions may have great potential with one manure handling technique while being ineffective for another. Therefore, the objective of this study is to assess the effects of dietary protein manipulation on ammonia emissions from relatively freshly voided dairy cow manure in three types of handling systems: scraped manure removal systems, flushed manure removal systems, and flushed manure removal systems with a solids separator. 


\section{Materials ANd Methods DIETS}

The Virginia Tech Animal Care and Use Committee approved all animal procedures. Experiments were conducted from the spring of 2006 to the spring of 2007 in parallel with an investigation into nitrogen digestion and metabolism as a function of dietary composition (Cyriac et al., 2011). Cows were fed four treatment diets with dietary crude protein contents of $15.0 \%, 15.9 \%, 16.9 \%$, and $17.8 \%$. Forage, a mix of $83 \%$ corn silage and $17 \%$ alfalfa and grass silage, comprised $48 \%$ of dry matter in all diets. The grain mix that made up $52 \%$ of the diet was a combination of corn, soyhulls, soybean meal, ruminally protected soybean meal, and tallow. Proportions of ingredients in the grain mix were manipulated to achieve the targeted crude protein densities while maintaining constant dietary energy levels.

Dietary treatments were applied over four intervals of 21 $\mathrm{d}$ each with three Holstein cows and then again with four different cows. Each feeding interval consisted of $14 \mathrm{~d}$ of acclimatization followed by $5 \mathrm{~d}$ of manure collection. One cow was inadvertently removed from the study by the farm staff after the third interval of the first replication, and one cow missed the first two intervals of sampling in the second replication due to health problems. The resulting numbers of observations were 5, 5, 4, and 6 for the $15.0 \%, 15.9 \%, 16.9 \%$, and $17.8 \%$ crude protein diets, respectively. During the acclimatization period, cows were housed in a free-stall barn and individually fed via Calan doors (American Calan, Northwood, N.H.).

\section{Manure Collection}

The manure collection protocol was designed to minimize ammonia losses to the atmosphere prior to flux measurements and to gather subsamples for analysis of $\mathrm{pH}$, total Kjeldahl nitrogen (TKN), and total ammoniacal nitrogen (TAN). During the manure collection period, cows were housed in individual stalls, and urine and feces were collected separately to prevent conversion of urea to ammonia by urease in the feces and minimize losses of ammonia. While collection with real manure handling systems (i.e., scrape and flush) would have been desirable, such an approach was not appropriate for the goals and design of the experiment.

Urine was collected from each cow via urinary catheter connected to tubing placed in $19 \mathrm{~L}$ jugs. Except for the first interval of the first replicate, urine was chilled on ice during collection to prevent urea catalysis (Knowlton et al., 2010). Every $24 \mathrm{~h}$, urine jugs were weighed, and $50 \mathrm{~mL}$ subsamples were collected, acidified, and frozen. The remaining urine in the jugs was stored frozen until further testing. Feces were collected from each cow in a tray beneath the slatted floor of each stall. Every $24 \mathrm{~h}$, feces were transferred from the trays to plastic $132 \mathrm{~L}$ (35 gal) drums for weighing. Feces in each drum were mixed using a heavy-duty drill and paddle bit, and $\sim 500 \mathrm{~g}$ subsamples were collected for analysis in plastic bags. Following feces collection, the drums were sealed with lids and stored frozen until further testing. Freezing manure prior to ammonia analyses is commonly practiced, and there is no evidence that freezing affects the results (Cole et al., 2005; James et al., 1999).

\section{Manure Preparation}

The urine and feces that had been collected and frozen were thawed separately prior to testing and then prepared to simulate removal from animal housing by scraping, flushing, or flushing followed by solids separation. Representing the three approaches, four streams of manure were produced: scraped, flushed, separated solids, and separated liquids. These four streams will be referred to as "types" of manure.

The study was divided into two periods. The intent of the first period was to mimic natural conditions, while the intent of the second period was to establish greater control over manure and environmental conditions to allow assessment of their effects. In the first period, urine and feces were combined at the ratio excreted. The urine-to-feces ratio averaged $0.50 \pm 0.04$ across cows and diets. In the second period, a constant urine-to-feces mass ratio of 0.50 in all manure samples was maintained. Table 1 lists the experimental conditions for each of the manure samples. Each row of the table represents a particular cow and dietary crude protein content; the manure from each cow-diet combination was prepared as four different types of manure (scraped, flushed, separated solids, and separated liquids) for measurement of ammonia emissions.

Each type of manure was prepared in an $80 \mathrm{~L}$ bin (the bottom portion of a plastic 35 gal drum) separately for each cow. For scraped manure, one-quarter of the urine and feces excreted over $24 \mathrm{~h}$ was added to a bin and mixed manually with a paddle. For flushed manure, one-quarter of the urine and feces, along with fresh water at a water-to-manure ratio of $4: 1$ by weight (the same ratio used by the flushing system

\begin{tabular}{|c|c|c|c|c|c|}
\hline & Cow & $\begin{array}{l}\% \text { Crude } \\
\text { Protein }\end{array}$ & $\begin{array}{l}\text { Mixing } \\
\text { Intensity }\end{array}$ & $\begin{array}{c}\text { Temperature } \\
\text { Control[a] }\end{array}$ & $\begin{array}{c}\text { Urine/ } \\
\text { Feces }[\mathrm{b}]\end{array}$ \\
\hline \multirow[t]{8}{*}{ Period 1} & \multirow[t]{3}{*}{ A } & 17.8 & Low & No & 0.38 \\
\hline & & 15.9 & Low & No & 0.43 \\
\hline & & 15.0 & Low & No & 0.42 \\
\hline & \multirow[t]{2}{*}{ B } & 17.8 & Low & No & 0.61 \\
\hline & & 16.9 & Low & No & 0.51 \\
\hline & \multirow[t]{3}{*}{$\mathrm{C}$} & 17.8 & Low & No & 0.67 \\
\hline & & 16.9 & Low & No & 0.52 \\
\hline & & 15.0 & Low & No & 0.52 \\
\hline \multirow[t]{12}{*}{ Period 2} & \multirow[t]{3}{*}{ D } & 17.8 & High & Yes & 0.50 \\
\hline & & 16.9 & High & Yes & 0.50 \\
\hline & & 15.0 & High & Yes & 0.51 \\
\hline & \multirow[t]{3}{*}{$\mathrm{E}$} & 16.9 & High & Yes & 0.50 \\
\hline & & 15.9 & High & Yes & 0.46 \\
\hline & & 15.0 & High & Yes & 0.50 \\
\hline & \multirow[t]{3}{*}{$\mathrm{F}$} & 16.9 & High & Yes & 0.50 \\
\hline & & 15.9 & High & Yes & 0.50 \\
\hline & & 15.0 & High & Yes & 0.50 \\
\hline & \multirow[t]{3}{*}{ G } & 17.8 & High & Yes & 0.50 \\
\hline & & 16.9 & High & Yes & 0.50 \\
\hline & & 15.0 & High & Yes & 0.50 \\
\hline
\end{tabular}

[a] Indicates whether the temperature in the barn where emissions measurements took place was uncontrolled and allowed to fluctuate naturally (period 1) or was controlled to $15^{\circ} \mathrm{C}$ (period 2$)$.

[b] Mass ratio in manure, as prepared for emissions testing. In period 1, this was the ratio as excreted; in period 2, urine and feces were mixed at a ratio as close to 0.50 as possible regardless of the ratio as excreted. 
at the Virginia Tech dairy barn), was added to a bin. The slurry was mixed thoroughly with a paddle. For separated solids and liquids, half of the urine and feces, along with fresh water at a water-to-manure ratio of $4: 1$ by weight, was added to a bin. The slurry was mixed thoroughly with a paddle. The bin was covered and allowed to sit for $24 \mathrm{~h}$ to simulate the storage period prior to separation. The manure slurry was then separated into solids and liquids using a pilot-scale mechanical manure solids separator (Knowlton et al., 2005). Separated liquids and solids were transferred separately back to $80 \mathrm{~L}$ bins for measurement of ammonia emissions.

\section{Manure AnAlysis}

Subsamples of manure were collected in $250 \mathrm{~mL}$ bottles at the beginning and end of emissions measurements for analysis. The subsamples were acidified and stored at $4{ }^{\circ} \mathrm{C}$ for later analysis. In the second period, the manure was vigorously mixed with egg-beaters prior to subsampling, and analyses were expanded to include TAN.

\section{MeASUREMENT OF EMisSions}

Ammonia emissions were measured using a custom-built dynamic flux chamber ( $\mathrm{Li}$ et al., 2009), whose design was based on previous studies by the U.S. Environmental Protection Agency and others (Eklund, 1992; Mukhtar et al., 2009). The clear acrylic chamber was a $45.7 \mathrm{~cm}$ (18 in.) cylinder with a domed top and a total volume of $49 \mathrm{~L}$. It was placed on top of manure in the $80 \mathrm{~L}$ bins. Sweep air at a flow rate of $7 \mathrm{~L} \mathrm{~min}^{-1}$ entered through perforated Teflon tubing that encircled the inside of the chamber and exited through an outlet and vent hole near the top of the dome. Temperatures of the manure, the chamber headspace, and the outside air were logged continuously (Hobo, Bourne, Mass.).

Ammonia concentrations in the outlet from the chamber's headspace were measured using a photoacoustic infrared (IR) analyzer (Innova Air Tech 1312, Ballerup, Denmark) programmed to sample at intervals varying between $30 \mathrm{~s}$ and $5 \mathrm{~min}$. The instrument has a detection limit of $1.4 \times 10^{-1} \mathrm{mg}$ $\mathrm{m}^{-3}$ and was factory calibrated (California Analytical, Orange, Cal.) one month prior to the study.

The ammonia flux as a function of time, $F(t)\left(\mathrm{mg} \mathrm{m}^{-2} \mathrm{~s}^{-1}\right)$, was calculated as:

$$
F(t)=\frac{Q\left[\mathrm{NH}_{3}\right](t)}{A}
$$

where $Q$ is the volume flow rate through the chamber $\left(0.42 \mathrm{~m}^{3} \mathrm{~s}^{-1}\right), \quad\left[\mathrm{NH}_{3}\right](t)$ is the ammonia concentration $\left(\mathrm{mg} \mathrm{m}^{-3}\right)$ measured at the chamber outlet at time $t$, and $A$ is the surface area covered by the chamber $\left(0.16 \mathrm{~m}^{2}\right)$. The chamber was validated by comparing loss of aqueous ammonium from a known volume and concentration of a control solution (333 $\mathrm{mg} \mathrm{NH}_{3}-\mathrm{N} \mathrm{mL} \mathrm{mL}^{-1}$ ) placed inside the chamber to the measured gaseous flux. Recoveries of emissions from the control solution were not significantly different from $100 \%$, indicating that depositional losses of ammonia to the chamber surfaces were negligible.

Experiments were conducted in a building located $\sim 200 \mathrm{~m}$ from the main barn. Ambient air drawn from outdoors served as the sweep air; its ammonia concentration averaged $0.31 \mathrm{mg} \mathrm{m}^{-3}$, which was at least two orders of magnitude lower than the concentrations typically exiting the chamber and could therefore be considered negligible. Before each test, sweep air was pumped though the chamber for $\sim 30 \mathrm{~min}$ (3.5 residence times). The duration of flux measurements was $12 \mathrm{~h}$, intended to account for manure removal twice per day on real farms, and in some cases experiments continued for up to $4 \mathrm{~d}$ to allow observation of long-term patterns in emissions. In the first period of the study, temperatures were allowed to vary with ambient conditions, and in the second period of the study, the building temperature was controlled to $15^{\circ} \mathrm{C}$.

\section{Data Analysis}

Emissions were expressed in mass of ammonia per area per minute (eq. 1), mass of ammonia per mass of manure excreted per minute, and mass of ammonia per cow per day. Under the conditions of this study, ammonia flux was sensitive to temperature (e.g., correlation coefficient of 0.73 , after the initial rise in flux, in the experiment lasting $4 \mathrm{~d}$ ); therefore, all measured fluxes were adjusted to a common temperature of $15^{\circ} \mathrm{C}$, the average observed across all measurements. For reference, the average annual temperature in the state of Virginia is $13^{\circ} \mathrm{C}$. The temperature adjustment was based on the sensitivity of ammonia flux to gas-liquid partitioning (i.e., Henry's constant). The flux can be described quantitatively by the convective mass transfer equation:

$$
F=k\left(\left[\mathrm{NH}_{3}\right]_{\text {bound }}-\left[\mathrm{NH}_{3}\right]_{\text {air }}\right)
$$

where $k$ is the mass transfer coefficient $\left(\mathrm{m} \mathrm{s}^{-1}\right)$, and $\left[\mathrm{NH}_{3}\right]_{\text {bound }}$ and $\left[\mathrm{NH}_{3}\right]_{\text {air }}$ are the gaseous ammonia concentrations just above the boundary of the liquid and in the bulk air (the chamber in our case), respectively (Monteny et al., 1998). The mass transfer coefficient depends on the air velocity and temperature according to the following relationship:

$$
k=48.4 v^{0.8} T^{-1.4}
$$

where $v$ is the air velocity $\left(\mathrm{m} \mathrm{s}^{-1}\right)$ and $T$ is the temperature $(\mathrm{K})$ (Elzing and Monteny, 1997). $\left[\mathrm{NH}_{3}\right]_{\text {bound }}$ in the gaseous phase is in equilibrium with the ratio of $\left[\mathrm{NH}_{3}\right]_{\text {liq, bound, the ammonia }}$ concentration in the liquid at the boundary layer, to Henry's constant $K_{H}$ :

$$
\left[\mathrm{NH}_{3}\right]_{\text {bound }}=\frac{\left[\mathrm{NH}_{3}\right]_{\text {liq,bound }}}{K_{H}}
$$

Henry's constant for ammonia varies with temperature according to the following relationship (Elzing and Monteny, 1997; Hashimoto and Ludington, 1971):

$$
K_{H}=1384 \times 1.053^{(293-T)}
$$

where both $\left[\mathrm{NH}_{3}\right]_{\text {bound }}$ and $\left[\mathrm{NH}_{3}\right]_{\text {liq, bound }}$ are in the same mass per volume units (e.g., $\mathrm{mg} \mathrm{L}^{-1}$ ). Over the range of temperatures encountered during the experiments, $0^{\circ} \mathrm{C}$ to $25^{\circ} \mathrm{C}, K_{H}$ varied by a factor of 3.6, while the mass transfer coefficient varied by less than $12 \%$ (less than a factor of 1.12 ) for the very low air velocities measured inside the chamber. Therefore, the flux is approximately inversely proportional to Henry's constant, and measured fluxes could be adjusted to a temperature of $15^{\circ} \mathrm{C}$ as follows:

$$
F_{15^{\circ} \mathrm{C}}(t)=1.053^{(288-T(t))} F(t)
$$


These adjusted fluxes were then used to calculate the emission factors. The adjustment for temperature considerably smoothes out the diurnal variation in ammonia fluxes and therefore appears to be appropriate for this data set.

Data analysis focused on assessing relationships between the different metrics of emissions as effects and dietary crude protein content and type of manure as predictors. The Means, Anova, Compare Means, Fit Line, and Fit Model procedures of JMP (SAS Institute, Inc., Cary, N.C.) were used to perform the analyses. Significant differences were determined at $\mathrm{p}<$ 0.05 .

\section{Results AND Discussion}

In the first period of the study, 31 total measurements (one was lost due to instrumental errors) of ammonia fluxes from scraped manure, flushed manure, separated liquids, and separated solids were completed under temperature-varying, gently mixed conditions, intended to mimic realistic circumstances during manure handling on a farm. In the second period, 48 measurements were completed under temperature-controlled, vigorously mixed conditions with a fixed ratio of urine to feces. These conditions were intended to provide greater experimental control compared to the first period.

\section{Manure Properties}

Table 2 summarizes manure properties as a function of manure type. As shown later, dietary crude protein content did not impact any of these quantities except for emission factors on a per-cow basis, so results have been combined across diets. The $\mathrm{pH}$ of scraped and flushed manure was initially neutral, while that of the separated solids and liquids, which had been stored as flushed manure for $24 \mathrm{~h}$, was basic $(\geq 8.5)$. While the $\mathrm{pH}$ of the latter two manure types did not change over the course of the experiments, the $\mathrm{pH}$ of scraped and flushed manure rose to match that of the separated solids and liquids, most likely due to release of carbon dioxide (Chaoui et al., 2009; Ni, 1999; Sommer and Sherlock, 1996). Initial TKN concentrations were $3.9 \pm 1.2$ and $4.1 \pm 0.9$ times higher in scraped manure than in flushed in the first and second periods, respectively, not significantly different from the five-fold difference that would be predicted from the dilution ratio. TKN concentrations were comparable in flushed manure and the separated liquids and at least $1.5 \pm 0.2$ times higher in the separated solids. For any specific type of manure, initial and final TKN concentrations were not significantly different, so in terms of a mass balance, the amount of ammonia emitted during testing (i.e., nitrogen lost) was very small compared to the total amount of nitrogen in the prepared manure. Initial TAN concentrations were much higher in separated solids and liquids compared to flushed manure (not separated), by a factor of $8.3 \pm 3.5$ for separated liquids and $7.6 \pm 3.0$ for solids. However, final TAN concentrations were comparable across all three types of manure for which measurements were available. Analysis of TAN in scraped manure was compromised because samples containing large amounts of solids froze too slowly to halt hydrolysis of urea, and therefore these values are shown as "NA" in table 2.

Table 2. Manure properties and ammonia emissions (mean \pm standard deviation) at $15^{\circ} \mathrm{C}$ over $12 \mathrm{~h}$ for four types of manure.

\begin{tabular}{|c|c|c|c|c|c|}
\hline & & Scraped & Flushed & Separated Solids & Separated Liquids \\
\hline \multirow[t]{12}{*}{ Period 1[a] } & Initial $\mathrm{pH}$ & $6.8 \pm 0.3$ & $7.0 \pm 0.2$ & $8.9 \pm 0.3$ & $8.6 \pm 0.2$ \\
\hline & Final pH & $8.0 \pm 0.5$ & $8.6 \pm 0.2$ & $8.9 \pm 0.3$ & $8.6 \pm 0.1$ \\
\hline & Initial TKN $\left(\mathrm{mg} \mathrm{L}^{-1}\right)$ & $4800 \pm 1200$ & $1200 \pm 200$ & $1900 \pm 400$ & $1200 \pm 200$ \\
\hline & Final TKN (mg L-1) & $4400 \pm 1100$ & $1100 \pm 200$ & $1700 \pm 400$ & $1100 \pm 200$ \\
\hline & Prepared manure slurry tested $(\mathrm{kg})$ & $14.4 \pm 3.0$ & $20.9 \pm 1.2$ & $5.0 \pm 2.1$ & $21.0 \pm 1.0$ \\
\hline & Manure equivalent as excreted $(\mathrm{kg})$ & $14.4 \pm 3.0$ & $4.2 \pm 0.2$ & $28 \pm 7$ & $5.0 \pm 0.4$ \\
\hline & Urine/feces ratio & $0.47 \pm 0.13$ & $0.55 \pm 0.17$ & $0.50 \pm 0.12$ & $0.50 \pm 0.09$ \\
\hline & Average $\mathrm{NH}_{3}$ flux $\left(\mathrm{mg} \mathrm{m}^{-2} \mathrm{~min}^{-1}\right)$ & $1.6 \pm 0.8$ & $0.6 \pm 0.3$ & $2.1 \pm 0.8$ & $2.2 \pm 0.8$ \\
\hline & Final $\mathrm{NH}_{3}$ flux $\left(\mathrm{mg} \mathrm{m}^{-2} \mathrm{~min}^{-1}\right)$ & $2.4 \pm 1.0$ & $0.9 \pm 0.5$ & $1.9 \pm 0.7$ & $2.1 \pm 0.7$ \\
\hline & $\mathrm{NH}_{3}$ emission factor: & & & & \\
\hline & per manure excreted $\left(\mathrm{mg} \mathrm{kg}^{-1} \mathrm{~h}^{-1}\right)$ & $1.2 \pm 0.5$ & $1.4 \pm 0.7$ & $0.8 \pm 0.4$ & $5.0 \pm 1.9$ \\
\hline & per cow $\left(g \operatorname{cow}^{-1} d^{-1}\right)$ & $1.6 \pm 0.8$ & $2.1 \pm 1.3$ & $1.0 \pm 0.3$ & $6.0 \pm 2.6$ \\
\hline \multirow[t]{14}{*}{ Period 2} & Initial $\mathrm{pH}$ & $6.9 \pm 0.4$ & $7.1 \pm 0.3$ & $8.5 \pm 0.4$ & $8.5 \pm 0.2$ \\
\hline & Final pH & $8.6 \pm 0.2$ & $8.5 \pm 0.2$ & $8.9 \pm 0.1$ & $8.4 \pm 0.3$ \\
\hline & Initial TKN $\left(\mathrm{mg} \mathrm{L}^{-1}\right)$ & $6600 \pm 1200$ & $1600 \pm 200$ & $2400 \pm 200$ & $1500 \pm 300$ \\
\hline & Final TKN $\left(\mathrm{mg} \mathrm{L}^{-1}\right)$ & $5400 \pm 1200$ & $1600 \pm 200$ & $2500 \pm 200$ & $1400 \pm 200$ \\
\hline & Initial TAN $\left(\mathrm{mg} \mathrm{L}^{-1}\right)^{[\mathrm{b}]}$ & NA & $80 \pm 20$ & $600 \pm 200$ & $700 \pm 200$ \\
\hline & Final TAN $\left(\mathrm{mg} \mathrm{L}^{-1}\right)^{[\mathrm{b}]}$ & NA & $700 \pm 200$ & $600 \pm 200$ & $900 \pm 300$ \\
\hline & Prepared manure slurry tested $(\mathrm{kg})$ & $7.9 \pm 0.1$ & $17.7 \pm 1.2$ & $4.1 \pm 0.5$ & $18.1 \pm 1.3$ \\
\hline & Manure equivalent as excreted $(\mathrm{kg})$ & $7.9 \pm 0.1$ & $3.5 \pm 0.2$ & $16.3 \pm 0.3$ & $4.6 \pm 0.3$ \\
\hline & Urine/feces ratio & $0.50 \pm 0.00$ & $0.51 \pm 0.01$ & $0.49 \pm 0.02$ & $0.50 \pm 0.02$ \\
\hline & Average $\mathrm{NH}_{3}$ flux $\left(\mathrm{mg} \mathrm{m}^{-2} \mathrm{~min}^{-1}\right)$ & $3.3 \pm 1.8$ & $0.6 \pm 0.2$ & $1.8 \pm 0.6$ & $1.6 \pm 0.6$ \\
\hline & Final $\mathrm{NH}_{3}$ flux $\left(\mathrm{mg} \mathrm{m}^{-2} \mathrm{~min}^{-1}\right)$ & $5.4 \pm 2.7$ & $1.0 \pm 0.3$ & $1.6 \pm 0.6$ & $1.8 \pm 0.7$ \\
\hline & $\mathrm{NH}_{3}$ emission factor: & & & & \\
\hline & per manure excreted $\left(\mathrm{mg} \mathrm{kg}^{-1} \mathrm{~h}^{-1}\right)$ & $4.1 \pm 2.2$ & $1.6 \pm 0.5$ & $1.1 \pm 0.4$ & $4.2 \pm 1.5$ \\
\hline & per cow $\left(g \operatorname{cow}^{-1} d^{-1}\right)$ & $4.9 \pm 3.4$ & $1.8 \pm 0.8$ & $1.2 \pm 0.4$ & $4.8 \pm 1.4$ \\
\hline
\end{tabular}

[a] Period 1: Ambient temperature, moderate mixing, variable urine/feces ratio; Period 2: Controlled temperature, vigorous mixing, fixed urine/feces ratio [b] TAN was not measured during the first period. 
Differences between the two periods were manifested in the $\mathrm{pH}$, TKN concentration, and ammonia emission rate for certain types of manure. For separated solids, the initial $\mathrm{pH}$ was higher in the first period than in the second, and for scraped manure, the final $\mathrm{pH}$ was higher in the second period compared to the first. For all types of manure, the initial TKN concentration was higher in the second period compared to the first, and for all but flushed manure, the final TKN concentration was also higher in the second period. More vigorous mixing during the second period prior to sampling for chemical analysis might have improved suspension of solids and thus increased TKN values.

\section{Ammonia Emissions}

The temporal pattern of emissions differed substantially with type of manure. It is commonly assumed that there is a burst of ammonia emissions from manure as soon as urine and feces come into contact with each other (Beauchamp et al., 1982; Sommer et al., 1991). In fact, emissions from scraped and flushed manure rose gradually from zero over a period of 12 to $24 \mathrm{~h}$ (fig. 1), while those from separated solids and liquids were relatively constant across this time frame. Similarly, James et al. (1999) observed that emissions peaked 10 to $15 \mathrm{~h}$ after urine and feces were mixed. The slope of the scraped manure time series was four times higher than that of the flushed manure time series, a factor similar to the dilution ratio of 5 used in preparing the flushed manure. Fluxes from the separated liquids and separated solids were nearly equal in magnitude. These observations contrasting temporal trends in ammonia emissions from the different manure types were consistent across all cows and all diets. In a handful of experiments run over longer periods (not shown), fluxes from scraped and flushed manure eventually leveled off after $\sim 12$ to $24 \mathrm{~h}$.

The difference in the temporal patterns of emissions between types of manure stems from compositional changes in the slurry during storage prior to separation. In fresh, flushed manure, initial TAN concentrations were low, 80 $\pm 20 \mathrm{mg} \mathrm{L}^{-1}$, as compared to $600 \pm 200 \mathrm{mg} \mathrm{L}^{-1}$ and 800 $\pm 200 \mathrm{mg} \mathrm{L}^{-1}$ in separated solids and liquids, respectively. The initial TAN/TKN ratio was $5 \% \pm 2 \%$ in flushed manure, comparable to that reported by others (Bristow et al., 1992).

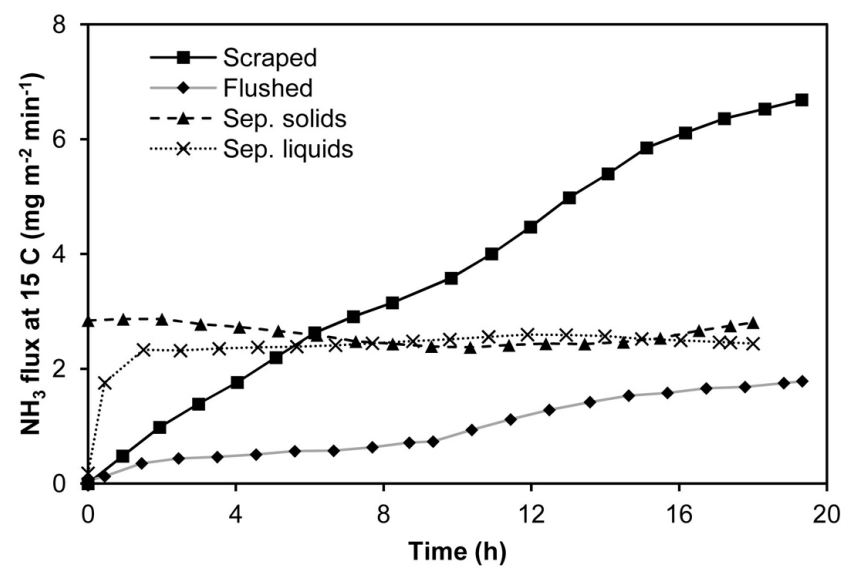

Figure 1. Time series of temperature-corrected ammonia flux, adjusted to $15^{\circ} \mathrm{C}$, from four different types of manure from the same cow on the $17.8 \%$ crude protein diet.
Most nitrogen is excreted in the form of urea, which is rapidly converted to ammonium by urease. More importantly, the initial $\mathrm{pH}$ of the scraped and flushed manures was neutral, much lower than the $\mathrm{pK}_{\mathrm{a}}$ of 9.3 at $25^{\circ} \mathrm{C}$, meaning that ammonium was greatly favored over aqueous ammonia in the acid-base equilibrium. By the end of the experiments, the $\mathrm{pH}$ of the flushed and scraped manures had risen to $8.6 \pm 0.2$ and $8.5 \pm 0.2$ (table 2) due to release of carbon dioxide (Chaoui et al., 2009; Ni, 1999; Sommer and Sherlock, 1996), and ammonia fluxes reached their maxima. In contrast, the separated solids and liquids were from flushed slurry that had been aged for $24 \mathrm{~h}$ prior to separation, during which urea had been converted to ammonium (initial TAN/TKN ratios of $25 \% \pm 7 \%$ and $45 \% \pm 15 \%$ in solids and liquids, respectively), and the $\mathrm{pH}$ of each had already risen to above 8. In fact, in the separated liquids and solids, the final TKN concentrations, TAN concentrations, and $\mathrm{pH}$ values were unchanged from their initial values.

The final four rows of each section of table 2 show ammonia emissions, adjusted to $15^{\circ} \mathrm{C}$, expressed four ways: average and final fluxes, emission factors per mass of manure excreted, and emission factors per cow. Those values from the first, more realistic, experimental period are also shown in figure 2. Ammonia emissions varied by type of manure, but their relative ranking depended on how emissions were reported. In terms of fluxes (mass emitted per surface area per time), emissions were significantly higher from scraped versus flushed manure, not surprisingly, as scraped manure is much more concentrated. In the first period, time-averaged fluxes from scraped manure were $2.8 \pm 1.9$ higher than from flushed manure, and in the second period, the ratio was 5.9 \pm 3.7 . In the second period, fluxes from the separated solids and liquids fell between those of scraped and flushed manure.

On the basis of mass of ammonia emitted per mass of excreted manure (i.e., not including the dilution water), emissions from separated liquids were at least 3.1 \pm 1.9 times higher than from other types of manure in the first period, and emissions from both separated liquids and scraped manure were at least $2.2 \pm 1.1$ times higher than from the other two types of manure in the second period. When ammonia emission factors from the separated solids and separated liquids were summed to represent total emissions after separation, the combined emission factors were $5.8 \pm 2.0 \mathrm{mg}$ $\mathrm{kg}^{-1} \mathrm{~h}^{-1}$ in the first period and $5.3 \pm 4.3 \mathrm{mg} \mathrm{kg}^{-1} \mathrm{~h}^{-1}$ in the second period. Following separation, emissions from the

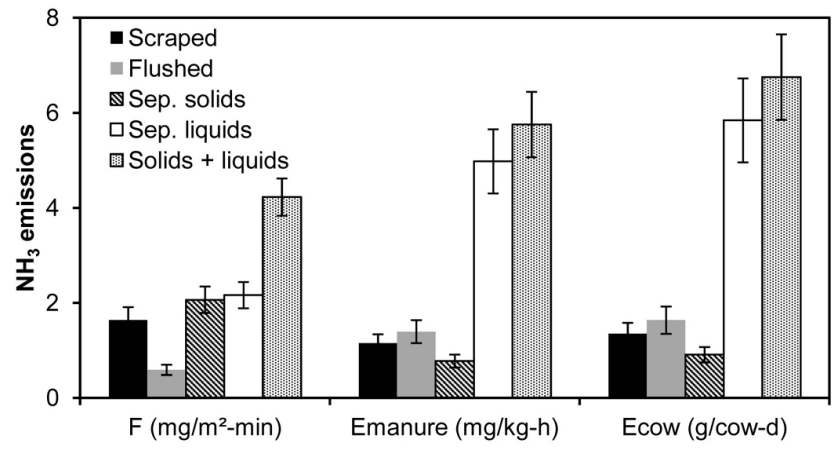

Figure 2. Ammonia released at $15^{\circ} \mathrm{C}$ over the first $12 \mathrm{~h}$ from four types of manure and from separated solids and liquids combined in terms of flux $(F)$, emission factor per mass of excreted manure $\left(E_{\text {manure }}\right)$, and emission factor per cow $\left(E_{c o w}\right)$. Bars represent standard errors. 

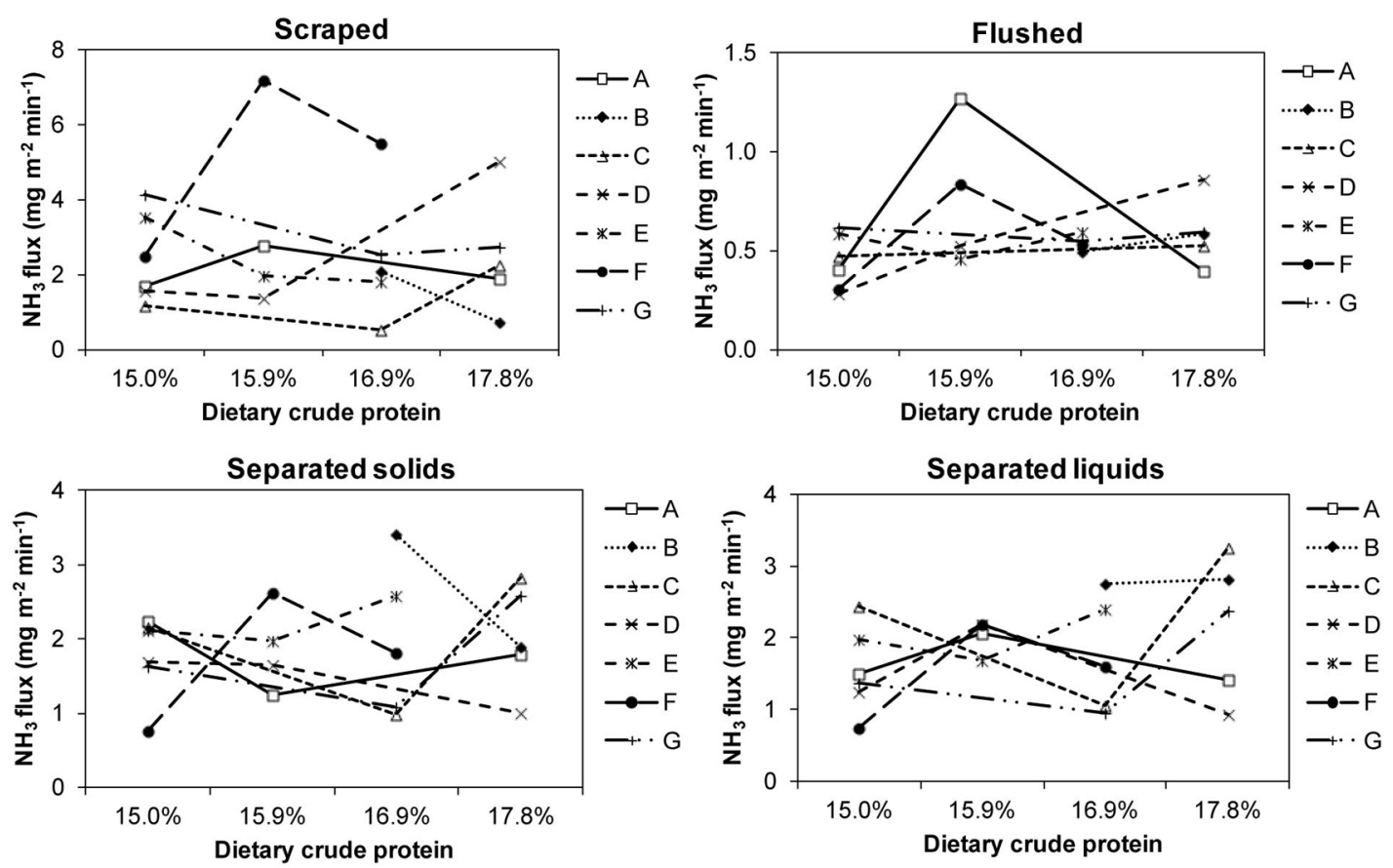

Figure 3. Ammonia fluxes, adjusted to $15^{\circ} \mathrm{C}$, over the first $12 \mathrm{~h}$ as a function of dietary crude protein content. Each graph represents one of four different types of manure and contains seven cows (A to $\mathrm{G}$ ). Lines are shown to guide the eye.

solids and liquids combined were $3.6 \pm 2.9$ and $2.9 \pm 0.6$ times higher than from flushed manure alone in the first and second periods, respectively. The comparison is not exact because the manure that underwent separation was aged for an additional $24 \mathrm{~h}$ prior to the flux measurement. These ratios were similar when emissions were calculated on a per-cow basis $\left(\mathrm{g} \mathrm{cow}^{-1} \mathrm{~d}^{-1}\right)$.

There were differences in emissions between the two periods. For scraped manure, ammonia emissions on the basis of mass of excreted manure and per cow were nearly four times higher in the second period, likely due to the promotion of contact between urea in the urine and urease in the feces by enhanced mixing. The process of diluting the other types of manure (flushed, separated solids and liquids) probably blended it sufficiently that further mixing action provided no added effect.

There was no apparent relationship between ammonia emissions in terms of flux and diet for any of the four different types of manure. Figure 3 shows average fluxes as a function of dietary crude protein content for individual cows. This perspective controls for cow-to-cow variability and differences between the study periods because cows A to C were exclusively part of the first period of the study, and cows $\mathrm{D}$ to $\mathrm{G}$ were exclusively part of the second period, when mixing was more vigorous and the urine/feces ratio held constant. There were no significant relationships between ammonia fluxes and actual crude protein intake per cow (i.e., accounting for total dry matter intake) for any of the types of manure. Although not shown, plots for individual cows of the emission factor in terms of manure excreted or per cow also showed no obvious association between dietary crude protein content and ammonia emissions.

The reason for the lack of relationship between dietary crude protein and ammonia fluxes in our study is that emis- sions were strongly correlated with TAN concentrations, as shown in figure 4 for the final ammonia flux versus the final TAN concentration, which did not vary with dietary crude protein content. The relationship was similar across all manure types for which TAN measurements were available (all but scraped manure). While dietary protein manipulation affected total nitrogen excreted, the effect was mediated through changes in volume of urine output rather than differences in TAN concentration in manure. Urinary output was $32 \%$ lower in cows fed the lowest crude protein diet as compared to cows fed the highest protein diet (Cyriac et al., 2011).

Estimates of ammonia emissions per cow per day as a function of dietary crude protein level, shown in figure 5, were also obtained by combining mean urine output across cows with the observed urine-to-feces ratio (fecal outputs

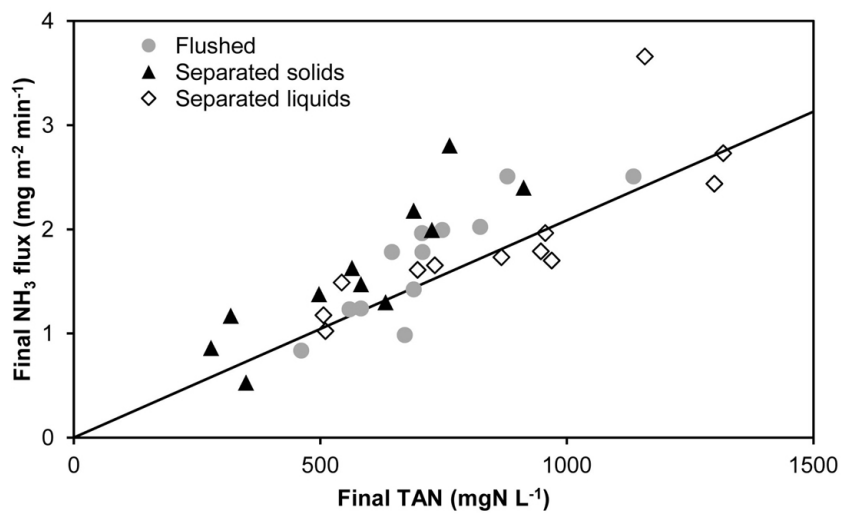

Figure 4. Final ammonia flux, adjusted to $15^{\circ} \mathrm{C}$, versus final TAN concentration for three types of manure. The regression line has a slope of 0.0021 and an intercept of 0.23 , with an $R^{2}$ of 0.66 . 


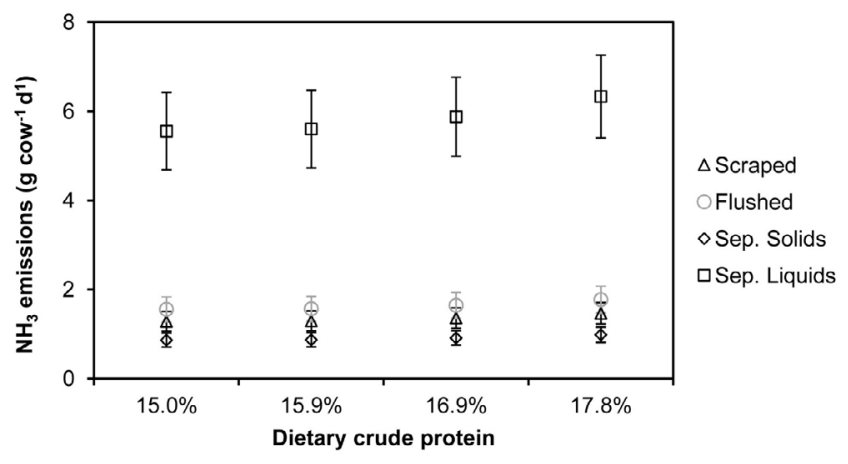

Figure 5. Per-cow ammonia emission factors at $15^{\circ} \mathrm{C}$ for four types of manure over the first $12 \mathrm{~h}$ as a function of dietary crude protein level. Bars represent standard errors.

were unaltered by diet) and mean emission factors ( $\mathrm{mg} \mathrm{kg}^{-1}$ $\mathrm{h}^{-1}$ ) from the first, more realistic, experimental period shown in table 2. On a per-cow basis, emissions were $\sim 4$ times higher from separated liquids than from the other types of manure. Emission factors were $12 \%$ lower for the lowest crude protein diet versus the highest one, but the slopes of the least-squares linear regression lines were not different from zero at the predefined significance level of 0.05 (the p-value was 0.06), although they were different at a level of 0.10 .

As reviewed by Ndegwa et al. (2008), several studies have shown that dietary crude protein levels are related to ammonia emissions from dairy cow manure. Results from these and other investigations are summarized in table 3 , along with results from the present study. Using a wide variety of methods and metrics of ammonia emissions, nearly all found a positive relationship between emissions and dietary crude protein. The most extreme difference was a $\sim 10$-fold difference in ammonia emissions measured in a laboratory-scale assessment of manure from cows fed diets containing $10.8 \%$ and $19 \%$ crude protein (van der Stelt et al., 2008). An evaluation involving cows housed in a mechanically ventilated barn yielded the observation that ammonia emissions were correlated with crude protein level in the fall season but not in the spring or winter (Powell et al., 2008). In general, it appears that larger changes in emissions with dietary protein levels were found in the more strictly controlled studies involving laboratory assessment, whereas smaller or no changes were found in the more realworld studies.

Table 3. Summary of studies on the relationship between dietary crude protein (CP) manipulation and ammonia emissions for cattle.

\begin{tabular}{|c|c|c|c|}
\hline Reference & $\begin{array}{l}\text { Dietary } \\
\text { CP Levels } \\
(\%)\end{array}$ & Method & Ammonia Emissions \\
\hline This study & $\begin{array}{l}15.0 \\
15.9 \\
16.9 \\
17.8\end{array}$ & $\begin{array}{l}\text { One-quarter of } 24 \mathrm{~h} \text { manure ( } 4 \text { to } 28 \mathrm{~kg} \text { ) in a } 49 \mathrm{~L} \\
\text { flux chamber for } 12 \text { to } 100 \mathrm{~h} \text {, for four types of } \\
\text { manure: undiluted, diluted, separated solids, and } \\
\text { separated liquids }\end{array}$ & $\begin{array}{l}\text { Emissions }\left(\mathrm{mg} \mathrm{m}^{-2} \mathrm{~min}^{-1} \text { and } \mathrm{mg} \mathrm{kg}^{-1}\right) \text { did not vary } \\
\text { with diet, but those per cow }\left(\mathrm{g} \mathrm{d}^{-1} \text { cow }^{-1}\right) \text { were lower } \\
\text { with lower CP diets. }\end{array}$ \\
\hline $\begin{array}{l}\text { Burgos et al. } \\
\quad(2010)\end{array}$ & $\begin{array}{l}15 \\
17 \\
19 \\
21\end{array}$ & $1 \mathrm{~kg}$ of manure in a $64.5 \mathrm{~L}$ flux chamber for $24 \mathrm{~h}$ & $\begin{array}{l}\text { Emissions }\left(\mathrm{g} \mathrm{d}^{-1} \text { cow }^{-1}\right) \text { increased linearly with } \mathrm{CP} \\
\text { content. }\end{array}$ \\
\hline $\begin{array}{l}\text { Powell et al. } \\
\quad(2008)\end{array}$ & $\begin{array}{c}16^{[\mathrm{a}]} \\
17 \\
19 \\
21\end{array}$ & $\begin{array}{l}\text { Manure in a sealed, ventilated tie-stall barn with } \\
\text { different types of bedding for } 28 \mathrm{~d} \text {. }\end{array}$ & $\begin{array}{l}\left.\text { Emissions ( } \mathrm{g} \mathrm{d}^{-1} \text { cow}^{-1}\right) \text { were lower with the lower } \mathrm{CP} \\
\text { diet during the fall but not spring or winter. }\end{array}$ \\
\hline $\begin{array}{l}\text { van der Stelt et al. } \\
\qquad(2008)\end{array}$ & $\begin{array}{c}10.8 \\
19\end{array}$ & $0.5 \mathrm{~kg}$ of manure in ventilated $1 \mathrm{~L}$ bottles for $32 \mathrm{~d}$. & $\begin{array}{l}\text { Emissions }\left(\mathrm{g} \mathrm{d}^{-1} \text { cow }^{-1}\right) \text { were } ~ 10 \text { times lower with the } \\
\text { lower CP diet. }\end{array}$ \\
\hline $\begin{array}{l}\text { Todd et al. } \\
\text { (2006) }\end{array}$ & $\begin{array}{l}11.5 \\
13.0\end{array}$ & $\begin{array}{l}\text { Manure in laboratory chambers for } 7 \mathrm{~d} \text { and by the } \\
\text { horizontal flux method on an artificial feedyard } \\
\text { surface for } 22 \text { to } 29 \mathrm{~d} \text {. }\end{array}$ & $\begin{array}{l}\text { Total ammonia lost }(\mathrm{mg}) \text { was } 44 \% \text { lower with the } \\
\text { lower CP diet in laboratory experiments. Field } \\
\text { emissions }\left(\mu \mathrm{g} \mathrm{m}^{-2} \mathrm{~s}^{-1}\right) \text { were } 28 \% \text { lower with the lower } \\
\text { CP diet. }\end{array}$ \\
\hline $\begin{array}{l}\text { Frank et al. } \\
\quad(2002)\end{array}$ & $\begin{array}{l}14 \\
19\end{array}$ & Manure in a flux chamber for $24 \mathrm{~h}$. & $\begin{array}{l}\text { Emissions }\left(\mathrm{mg} \mathrm{m}^{-2} \mathrm{~h}^{-1}\right) \text { were } 67 \% \text { lower with the } \\
\text { lower CP diet. }\end{array}$ \\
\hline $\begin{array}{l}\text { Frank and Swensson } \\
(2002)\end{array}$ & $\begin{array}{l}13 \\
17\end{array}$ & $\begin{array}{l}\text { One-third of } 24 \mathrm{~h} \text { manure in a flux chamber for an } \\
\text { unspecified period. }\end{array}$ & $\begin{array}{l}\text { Concentrations in outlet (ppm) were } 50 \% \text { lower with } \\
\text { the lower CP diet. }\end{array}$ \\
\hline $\begin{array}{l}\text { Kulling et al. } \\
\text { (2003) }\end{array}$ & $\begin{array}{l}12.5 \\
15.0 \\
17.5\end{array}$ & $\begin{array}{l}2.5 \text { to } 5 \mathrm{~kg} \text { of manure in an } 11.5 \mathrm{~L} \text { flux chamber } \\
\text { (including manure) for seven weeks, for four types } \\
\text { of manure: diluted, deep litter, farmyard, and diluted } \\
\text { urine-rich. }\end{array}$ & $\begin{array}{l}\text { Emissions }\left(\mu \mathrm{g} \mathrm{m}^{-2} \mathrm{~s}^{-1}\right) \text { were } 15 \% \text { to } 36 \% \text { lower with } \\
\text { the lowest vs. highest CP diet. Differences were } \\
\text { greatest for deep litter manure and least for farmyard } \\
\text { manure. }\end{array}$ \\
\hline $\begin{array}{l}\text { Krober et al. } \\
\quad(2000)\end{array}$ & $\begin{array}{l}12.4 \\
14.7 \\
17.5\end{array}$ & $\begin{array}{l}5 \mathrm{~kg} \text { of manure mixed with } 2.5 \mathrm{~kg} \text { of water in a flux } \\
\text { chamber for seven weeks. }\end{array}$ & $\begin{array}{l}\text { Emissions }\left(\mu \mathrm{g} \mathrm{m}^{-2} \mathrm{~s}^{-1}\right) \text { from diluted slurries were } 4.2 \\
\text { times lower with the lowest CP diet. }\end{array}$ \\
\hline $\begin{array}{l}\text { James et al. } \\
\text { (1999) }\end{array}$ & $\begin{array}{c}9.6 \\
11.0\end{array}$ & $\begin{array}{l}9 \mathrm{~g} \text { of manure at a fixed urine-to-feces ratio in a } 250 \\
\mathrm{~mL} \text { ventilated bottle for } 65 \mathrm{~h} \text {. }\end{array}$ & $\begin{array}{l}\text { Emissions }\left(\mathrm{g} \mathrm{d}^{-1} \text { cow }^{-1}\right) \text { were } 28 \% \text { lower with the } \\
\text { lower CP diet. }\end{array}$ \\
\hline $\begin{array}{l}\text { Paul et al. } \\
\text { (1998) }\end{array}$ & $\begin{array}{l}15.3 \\
16.7 \\
18.3\end{array}$ & $50 \mathrm{~g}$ of manure in a ventilated $1 \mathrm{~L}$ flask for $48 \mathrm{~h}$. & $\begin{array}{l}\text { Emissions }\left(\mathrm{mg} \mathrm{g}^{-1}\right) \text { were } \sim 30 \% \text { lower with the lowest } \\
\text { vs. highest CP diet. }\end{array}$ \\
\hline $\begin{array}{l}\text { Smits et al. } \\
\quad(1995)\end{array}$ & $\begin{array}{l}14.4 \\
19.8\end{array}$ & $\begin{array}{l}\text { Scraped and flushed manure in a mechanically } \\
\text { ventilated barn. }\end{array}$ & $\begin{array}{l}\text { Emission rates }\left(\mathrm{g} \mathrm{h}^{-1}\right) \text { were } 39 \% \text { lower with the lower } \\
\text { CP diet. }\end{array}$ \\
\hline
\end{tabular}

[a] Actual CP levels tested varied by season. 
While we have attempted to balance realistic scenarios with controlled experimental conditions in this study, there are limitations to the research. Experiments focused on emissions during the first $12 \mathrm{~h}$ following excretion in the case of scraped and flushed manure, and following separation (after $24 \mathrm{~h}$ of storage) in the case of separated solids and liquids. In reality, manure that will ultimately be flushed may sit on the barn floor for several hours before being diluted, in which case results for scraped manure are more applicable. Flushed manure was diluted with fresh water, while many farms use recycled liquid whose chemical composition may affect emissions. In addition, the duration of storage prior to separation may vary significantly between farms; this variable could also affect ammonia emissions.

\section{IMPLICATIONS}

The goal of this study was to determine the potential for dietary protein manipulation to reduce ammonia emissions from dairy cows during the initial stages of manure handling. The crude protein levels used in this study did not affect milk yield and composition, except for a quadratic response in total milk nitrogen and a linear decline in milk urea-nitrogen with decreasing dietary ruminally degradable protein (Cyriac et al., 2011).

Conclusions about the effect of diet on ammonia emissions from the early stages of manure handling depend on the measure of volatilization used. When evaluated as flux (mg $\mathrm{m}^{-2} \mathrm{~min}^{-1}$ ) or an emission factor based on the mass of excreted manure $\left(\mathrm{mg} \mathrm{kg}^{-1} \mathrm{~h}^{-1}\right)$, dietary protein manipulation had no effect on ammonia losses. But when evaluated as an emission factor based on the animal $\left(\mathrm{mg} \mathrm{cow}^{-1} \mathrm{~d}^{-1}\right)$, reducing crude protein content from $17.8 \%$ to $15.0 \%$ (a change of $16 \%$ ) resulted in a $12 \%$ decrease in ammonia losses without compromising milk production. The largest absolute impact of dietary protein manipulation on ammonia emissions would be with separated liquids because their cow-based emission factor is more than twice as high as those of the other types of manure. While fluxes from flushed manure were substantially lower than those from scraped manure and separated solids and liquids, the manure-based emission factor for flushed manure (fig. 2) was second highest among the four individual types of manure. These differences emphasize the importance of specifying the basis for comparison of ammonia emissions. The appropriate metric depends on the goal of the comparison. When comparing emissions from manure storage systems, for example, a flux may be more appropriate, whereas when estimating inventories, an animal-based emission factor may be more suitable.

The operating procedures of an individual dairy will play a critical role in determining what stage of handling contributes the majority of ammonia to the atmosphere. Beyond simply whether or not scraping or flushing is used, the storage duration, extent of mixing, and temperature associated with different stages of manure handling are variables that may affect ammonia emissions. The results from this study suggest that there are strategies that can be incorporated into a dairy's manure handling operation to measurably reduce ammonia emissions. Any interventions that reduce temperature and $\mathrm{pH}$ of manure and inhibit mixing of freshly excreted manure are likely to help limit ammonia volatilization. For instance, covering holding tanks prior to solids separation will minimize carbon dioxide stripping and prevent the $\mathrm{pH}$ from rising to levels favorable to ammonia mass transfer to the gaseous phase.

\section{Conclusions}

Dietary protein manipulation has the potential to reduce ammonia emissions from animal housing in the initial stages of manure handling. In this study, the effects of dietary crude protein levels and four types of manure (scraped, flushed, separated solids, and separated liquids) on ammonia emissions were investigated. A reduction in dietary crude protein from $17.8 \%$ to $15.0 \%$ (a change of 16\%) resulted in a $12 \%$ decrease in ammonia emissions on a per-cow basis from all four types of manure due to a reduction in urine output associated with reduced dietary protein. The largest absolute impact would be for separated liquids because its emission factor was approximately four times higher than for the other types of manure. Ammonia fluxes and emission factors per mass of manure were not affected by diet because fluxes were influenced mainly by TAN concentrations in the manure (and temperature), and these did not vary with diet.

The experimental methods used in this study fall somewhere between strictly controlled laboratory conditions and naturally occurring conditions. Likewise, results from this study indicate a moderate effect of dietary protein manipulation on ammonia emissions. Ammonia emissions have been shown to be most sensitive to dietary crude protein levels in more controlled experiments and not so sensitive in experiments conducted under more natural, operational conditions ( $\mathrm{Li}$ et al., 2009; Powell et al., 2008). The effectiveness of dietary protein manipulation to control ammonia emissions under natural conditions should be investigated further because emissions may be more sensitive to other factors with large variability in real-world situations on livestock farms.

\section{ACKNOWLEDGEMENTS}

This research was supported by National Research Initiative Competitive Grant 2006-35112-16635 from the USDA Cooperative State Research, Education, and Extension Service (CSREES). Shane Brannock, Aaron Cornman, Karen Hall, Jessica Ligon, Molly Reed, Agustin Rius, Julie Settlage, Sarah Slagle, and Chis Umberger provided assistance with the research.

\section{REFERENCES}

Aneja, V. P., W. H. Schlesinger, and J. W. Erisman. 2009. Effects of agriculture upon the air quality and climate: Research, policy, and regulations. Environ. Sci. Tech. 43(12): 4234-4240.

Beauchamp, E. G., G. E. Kidd, and G. Thurtell. 1982. Ammonia volatilization from liquid dairy cattle manure in the field. Canadian J. Soil Sci. 62(1): 11-19.

Bristow, A. W., D. C. Whitehead, and J. E. Cockburn. 1992. Nitrogenous constituents in the urine of cattle, sheep, and goats. J. Sci. Food and Agric. 59(3): 387-394.

Burgos, S. A., N. M. Embertson, Y. Zhao, F. M. Mitloehner, E. J. DePeters, and J. G. Fadel. 2010. Prediction of ammonia emissions from dairy cattle manure based on milk urea nitrogen: Relation of milk urea nitrogen to ammonia emissions. J. Dairy Sci. 93(6): 2377-2386. 
Chaoui, H., F. Montes, C. A. Rotz, and T. L. Richard. 2009. Volatile ammonia fraction and flux from thin layers of buffered ammonium solution and dairy cattle manure. Trans. ASABE 52(5): 1695-1706.

Cole, N. A., R. N. Clark, R. W. Todd, C. R. Richardson, A. Gueye, L. W. Greene, and K. McBride. 2005. Influence of dietary crude protein concentration and source on potential ammonia emissions from beef cattle manure. J. Animal Sci. 83(3): $722-731$

Cyriac, J., A. G. Rius, J. A. D. R. N. Appuhamy, R. E. Pearson, K. F. Knowlton, J. L. Firkins, A. N. Hristov, and M. D. Hanigan. 2011. Nitrogen digestion and metabolism of lactating dairy cows in response to varying dietary ruminally degradable protein. $J$. Dairy Sci. (submitted).

Eklund, B. 1992. Guidance for flux chamber measurements of fugitive volatile organic emission rates. J. Air and Waste Mgmt. Assoc. 42(12): 1583-1591.

Elzing, A., and G. J. Monteny. 1997. Ammonia emission in a scale model of a dairy-cow house. Trans. ASAE 40(3): 713-720.

Frank, B., and C. Swensson. 2002. Relationship between content of crude protein in rations for dairy cows and milk yield, concentration of urea in milk, and ammonia emissions. J. Dairy Sci. 85(7): 1829-1838.

Frank, B., M. Persson, and G. Gustafsson. 2002. Feeding dairy cows for decreased ammonia emission. Livestock Prod. Sci. 76(1): 171-179.

Hashimoto, A. G., and D. C. Ludington. 1971. Ammonia desorption from concentrated chicken manure slurries. In Proc. Intl. Symp. Livestock Wastes: Livestock Waste Management and Pollution Abatement, 117-121. St. Joseph, Mich.: ASAE.

James, T., D. Meyer, E. Esparza, E. J. Depeters, and H. Perez-Monti. 1999. Effects of dietary nitrogen manipulation on ammonia volatilization from manure from Holstein heifers. J. Dairy Sci. 82(11): 2430-2439.

Knowlton, K. F., N. G. Love, and C. M. Parsons. 2005. Dietary phosphorus effects on characteristics of mechanically separated dairy manure. Trans. ASAE 48(3): 1253-1258.

Knowlton, K. F., L. McGilliard, Z. Zhao, K. G. Hall, W. Mims, and M. D. Hanigan. 2010. Effective nitrogen preservation during urine collection from Holstein heifers fed diets with high or low protein content. J. Dairy Sci. 93(1): 323-329.

Krober, T. F., D. R. Kulling, H. Menzi, F. Sutter, and M. Kreuzer. 2000. Quantitative effects of feed protein reduction and methionine on nitrogen use by cows and nitrogen emission from slurry. J. Dairy Sci. 83(12): 2941-2951.

Kulling, D. R., H. Menzi, F. Sutter, P. Lischer, and M. Kreuzer. 2003. Ammonia, nitrous oxide and methane emissions from differently stored dairy manure derived from grass- and hay-based rations. Nutrient Cycling in Agroecosystems 65(1): 13-22.
Li, L. F., J. Cyriac, K. F. Knowlton, L. C. Marr, S. W. Gay, M. D. Hanigan, and J. A. Ogejo. 2009. Effects of reducing dietary nitrogen on ammonia emissions from manure on the floor of a naturally ventilated free-stall dairy barn at low (0-20 degrees $\mathrm{C})$ temperatures. J. Environ. Qual. 38(6): 2172-2181.

McCubbin, D. R., B. J. Apelberg, S. Roe, and F. Divita. 2002. Livestock ammonia management and particulate-related health benefits. Environ. Sci. Tech. 36(6): 1141-1146.

Monteny, G. J., D. D. Schulte, A. Elzing, and E. J. J. Lamaker. 1998. A conceptual mechanistic model for the ammonia emissions from free-stall cubicle dairy cow houses. Trans. ASAE 41(1): 193-201.

Mukhtar, S., A. Mutlu, R. E. Lacey, and C. B. Parnell. 2009. Seasonal ammonia emissions from a free-stall dairy in central Texas. J. Air Waste Mgmt. 59(5): 613-618.

Ndegwa, P. M., A. N. Hristov, J. Arogo, and R. E. Sheffield. 2008. A review of ammonia emission mitigation techniques for concentrated animal feeding operations. Biosyst. Eng. 100(4): 453-469.

Ni, J. 1999. Mechanistic models of ammonia release from liquid manure: A review. J. Agric. Eng. Res. 72(1): 1-17.

Novak, S. M., and J. L. Fiorelli. 2010. Greenhouse gases and ammonia emissions from organic mixed crop-dairy systems: A critical review of mitigation options. Agron. for Sustainable Development 30(2): 215-236.

Paul, J. W., N. E. Dinn, T. Kannangara, and L. J. Fisher. 1998. Protein content in dairy cattle diets affects ammonia losses and fertilizer nitrogen value. J. Environ. Qual. 27(3): 528-534.

Powell, J. M., G. A. Broderick, and T. H. Misselbrook. 2008. Seasonal diet affects ammonia emissions from tie-stall dairy barns. J. Dairy Sci. 91(2): 857-869.

Smits, M. C. J., H. Valk, A. Elzing, and A. Keen. 1995. Effect of protein nutrition on ammonia emission from a cubicle house for dairy cattle. Livestock Prod. Sci. 44(2): 147-156.

Sommer, S. G., and R. R. Sherlock. 1996. pH and buffer component dynamics in the surface layers of animal slurries. $J$. Agric. Sci. 127(1): 109-116.

Sommer, S. G., J. E. Olesen, and B. T. Christensen. 1991. Effects of temperature, wind speed, and air humidity on ammonia volatilization from surface-applied cattle slurry. J. Agric. Sci. 117(1): 91-100.

Todd, R. W., N. A. Cole, and R. N. Clark. 2006. Reducing crude protein in beef cattle diet reduces ammonia emissions from artificial feedyard surfaces. J. Environ. Qual. 35(2): 404-411.

Tomlinson, A. P., W. J. Powers, H. H. Van Horn, R. A. Nordstedt, and C. J. Wilcox. 1996. Dietary protein effects on nitrogen excretion and manure characteristics of lactating cows. Trans. ASAE 39(4): 1441-1448.

van der Stelt, B., P. C. J. van Vliet, J. W. Reijs, E. J. M. Temminghoff, and W. H. van Riemsdijk. 2008. Effects of dietary protein and energy levels on cow manure excretion and ammonia volatilization. J. Dairy Sci. 91(12): 4811-4821. 
